\title{
HUBUNGAN KONSEP DIRI DENGAN KECEMASAN NARAPIDANA PADA RUTAN KELAS II B MAJENE TAHUN 2019
}

\author{
Nurfadilah $^{1}$, Munadiah Wahyuddin ${ }^{2}, \operatorname{Irfan}^{3}$ \\ Program Studi S1 Keperawatan STIKes Marendeng Majene \\ Email : NurfadilahSyaifuddin@gmail.com
}

\section{THE RELATIONSHIP OF SELF-CONCEPT WITH NARAPIDANA ANXIETY ON CLASS II B MAJENE ROUTE}

\begin{abstract}
The concept of self is an individual's conceptualization of himself directly this self-concept affects the self-esteem and one's feelings towards himself. Self-concept is divided into 2 namely positive selfconcept and negative self-concept when an individual has a positive self-concept, his anxiety will be low whereas when an individual has a negative self-concept, his anxiety will be high. Prisoners are individuals who lose freedom where inmates experience anxiety which tends to be depressed due to their inability to adjust. The purpose of this study was to determine the relationship between selfconcept and prisoner anxiety. This type of research is observational analytic research with cross sectional study approach with the method of Simple Random Sampling. The instrument used was a questionnaire with a Likers Scale and HARS Scale. The sample in this study were 57 inmates. Based on the results of the Chi Square analysis showed that the hypothesis tested in the study was rejected with a significant value of 0.671 which means greater than 0.05 ( $p>0.05)$. It can be concluded that there is no significant relationship between self-concept and prisoners' anxiety in Majene Class II Prison. Suggestions for further researchers are to be able to add factors related to self-concept while adding samples to get more significant results.
\end{abstract}

Keyword : Self Concept, Anxiety, Inmate

\begin{abstract}
Abstrak
Konsep diri merupakan konseptualisasi individu terhadap dirinya sendiri secara langsung konsep diri ini berpengaruh terhadap harga diri serta perasaan seseorang terhadap dirinya sendiri. Konsep diri terbagi menjadi 2 yakni konsep diri positif dan konsep diri negatif ketika individu memiliki konsep diri yang positif maka kecemasannya akan rendah sedangkan ketika individu memiliki konsep diri yang negatif maka kecemasannya akan tinggi. Narapidana merupakan individu yang kehilangan kebebasan dimana narapidana mengalami kecemasan yang cenderung depresi akibat ketidakmampuan dalam menyesuaikan diri. Tujuan dari penelitian ini untuk mengetahui hubungan antara konsep diri dengan kecemasan narapidana. Jenis penelitian ini adalah penelitian analitik observasional dengan pendekatan cross sectional study dengan metode Simple Random Sampling. Instrumen yang digunakan adalah kuesioner dengan Skala likers dan Skala HARS. Sampel dalam penelitian sebanyak 57 orang narapidana. Berdasarkan hasil analisis Chi Square menunjukkan bahwa hipotesis yang diuji dalam penelitian ditolak dengan nilai signifikan sebesar 0,671 yang berarti lebih besar dari 0,05 ( $p>0,05)$. Dapat disimpulkan bahwa tidak ada hubungan yang signifikan antara konsep diri dengan kecemasan narapidana pada Rutan Kelas II B Majene. Saran bagi peneliti selanjutnya agar dapat menambahkan faktor-faktor terkait konsep diri sekaligus menambah sampel untuk mendapatkan hasil yang lebih signifikan.

Kata kunci: Konsep Diri, Kecemasan, Narapidana.
\end{abstract}




\section{PENDAHULUAN}

Narapidana adalah terpidana yang menjalani pidana hilang kemerdekaan di Lembaga Permasyarakatan (UU Nomor 12 Tahun 1995). Berdasarkan UU Nomor 12 Tahun 1995 Pasal 1 ayat (6) tentang permasyarakatan terpidana adalah seseorang yang dipidana berdasarkan putusan pengadilan yang telah memperoleh kekuatan hukum tetap. Pasal 1 ayat (7) tentang permasyarakatan, narapidana adalah terpidana yang menjalani pidana hilang kemerdekaan di Lembaga Permasyarakatan. Berdasarkan Undang-Undang Hukum Acara Pidana (KUHAP) Pasal 1 ayat (32) terpidana adalah seseorang yang dipidana berdasarkan putusan pengadilan yang telah memperoleh kekuatan hukum tetap.

Berdasarkan data dari Institute for Criminal Policy Research, pada tahun 2016 data global dari World Prison Brief lebih dari 10,35 juta orang didunia berada dalam tahanan Lembaga Pemasyarakatan dengan status sebagai tahanan Pra Persidangan maupun sebagai narapidana. Sejak pada tahun 2000 sampai 2015 meningkat narapidana terjadi pada seluruh dunia kecuali Benua Eropa dengan peningkatan sebesar 20 $\%$. Peningkatan pada Amerika Tengah sebesar 64\%, Asia Tenggara 40\%, di wilayah Oceania sebesar 59\%, Benua Amerika $41 \%$ sedangkan Benua Eropa mengalami penurunan sebesar $21 \%$ ini disebabkan karena Rusia dari tahun 2000 mengalami penurunan sebesar sekitar 1 juta orang dan pada tahun 2015 mengalami penurunan sebesar 640.000 orang (Data Institute for Criminal Justice Reform ). ${ }^{6}$

Pemantauan ICJR Sistem Database Pemasyarakatan (SDP) Direktorat Jenderal Pemasyarakatan Kementerian Hukum dan HAM 2017 menyatakan bahwa jumlah narapidana pada tingkat nasional sebanyak 161.342 orang. Data terakhir dari SDP jumlah penghuni Per-UPT kanwil Prov. SULBAR jumlah narapidana sebanyak 632 orang namun pada Lapas Kelas II B Polewali, Rutan Kelas II B Majene dan Rutan Kelas II B Mamuju dengan jumlah penghuni lebih besar dibandingkan kapasitas yang ada pada Rutan. ${ }^{7}$

Narapidana memiliki hak yang sama untuk mendapatkan derajat kesehatan yang optimal. Banyaknya penghuni pada Lapas menimbulkan permasalahan kesehatan pada narapidana terkait dengan masalah fisik dan psikologis. Masalah fisik diantaranya kondisi makanan serta pakaian sedangkan masalah terkait dengan psikologis berpengaruh terhadap berbagai tekanan di Lapas. Kondisi psikologis pada narapidana secara bertahap dan memberikan rendahnya kejahteraan 
psikologis serta memberikan dampak bagi narapidana yakni depresi, frustasi, rasa tidak aman, rendah diri, perasaan tidak berharga, rasa bersalah, malu, kecemasan dan selanjutnya ketakutan persepsi para narapidana tentang stigma masyarakat. ${ }^{15}$

Kecemasan adalah perasaan tertekan, tidak tenang dan pikiran kacau sehingga timbul penyesalan (Fitrotussalamah, 2016). Kecemasan yang dirasakan narapidana selama berada didalam Lapas kecenderungan mengalami depresi dimana perasaan itu muncul akibat ketidakmampuan individu dalam menyesuaikan diri dengan kecemasan yang dialami seperti khawatir, takut dan panik (Frans, 2014). Kecemasan seperti kekhawatiran dan ketakutan merupakan suatu keadaan yang berlebihan pada situasi yang membuat narapidana merasa khawatir dan takut mendapat penilaian negatif dari orang lain sehingga narapidana cenderung menghidari kegiatan sosial. ${ }^{3}$

Kecemasan pada narapidana memiliki ancaman pada jiwa dan psikis seperti kehilangan arti hidup dan merasa tidak berguna apalagi kecemasan tinggi akan mengalami gangguan pada masa depannya. ${ }^{5}$ Faktor kecemasan pada narapidana antara lain usia, lama hukuman, waktu menjelang bebas, dukungan keluarga, lingkungan serta konsep diri pada narapidana terganggu.$^{13}$
Konsep diri merupakan konseptualisasi individu terhadap dirinya sendiri secara langsung konsep diri ini berpengaruh terhadap harga diri serta perasaan seseorang terhadap dirinya sendiri (Potter \& Perry, 2010). Penilaian seorang narapidana terhadap dirinya sendiri secara keseluruhan baik fisik, psikis,moral maupun sosial. Konsep diri pada narapidana memiliki peran penting bagi para narapidana agar narapidana dapat membangun kepercayaan dirinya dalam menghadapi kehidupan setelah hukuman pidana selesai dan kembali ke lingkungan masyarakat. ${ }^{3}$

Konsep diri memiliki faktor predisposisi gangguan citra tubuh dengan merasa kehilangan bagian tubuh, terjadi perubahan pada bentuk, fungsi, ukura, penampilan kemudian faktor gangguan harga diri mencakup menarik diri, merasa tidak dihargai, pola asuh yang salah, adanya persaingan dan adanya kesalahan dengan tidak sampai pada standar selanjutnya faktor identitas diri meliputi ketidakpercayaan orang tua, keinginan yang terlalu tinggi, harapan yang tidak sesuai dengan keinginan, tekanan dari kelompok sebaya, adanya perubahan dari struktur sosial serta faktor gangguan peran adanya transisi peran, ketgangan peran, keraguan peran dan peran yang banyak. ${ }^{14}$ 
Konsep diri dapat dilihat bagaimana individu dalam bertindak pada berbagai situasi dimana konsep diri berperan dalam mengendalikan kecemasan semakin positif konsep diri yang dimiliki oleh narapidana maka akan besar kemungkinan rendahnya kecemasan yang timbul pada narapidana namun stigma negatif pada masyarakat tentang seorang narapidana dapat menjadi ancaman bagi konsep diri narapidana menyebabkan konflik emosional sehingga timbul kecemasan. ${ }^{4}$

Menurut penelitian (Putra, 2019)dan (Ekajaya, 2019) mengatakan bahwa ada hubungan antara konsep diri dengan kecemasan narapidana dilihat dari beberapa hipotesis yang ada kemudian melalui uji korelasi. Berbeda dengan penelitian yang dilakukan oleh (Fitrotussalamah, 2016) yang mengatakan bahwa tidak ada hubungan yang signifikan antara konsep diri dengan kecemasan narapidana.

Berdasarkan studi pendahuluan yang dilakukan pada Lapas Rutan Kelas II B Majene pada bulan April 2019 didapatkan jumlah narapidana sebanyak 67 orang hingga 20 April 2019 dengan hasil observasi dengan beberapa narapidana yang ada dilapas terkait kecemasan yang dirasakan napi berbeda-beda ada yang memikirkan keluarga, ekonomi keluarga, kurang nyaman dengan suasana yang ada pada lapas, ada juga yang biasa saja berada pada lapas, ada yang memikirkan pekerja serta ada yang kurang percaya diri, terhadap dirinya ketika akan kembali kemasyarakat.

Berdasarkan hasil uraian diatas maka peneliti tertarik untuk meneliti tentang hubungan konsep diri dengan kecemasan narapidana pada Rutan Kelas II B Majene. .

\section{BAHAN DAN METODE}

Metode penelitian yang digunakan adalah cross sectional dengan teknik sampling yang Simple Random Sampling. Peneliti mengacak dari semua nama-nama narapidana sebanyak 57 orang narapidana dengan peluang yang sama untuk menjadi subjek dalam penelitian. Setelah selesai peneliti mengacak nama-nama narapidana kemudian peneliti dan Tampling (Pendamping Tahanan) berdiskusi untuk pemanggilan narapidana yang menjadi subjek dalam penelitian.

Skala HARS berisikan 14 butir pertanyaan dengan jawaban ya dan tidak. Narapidana dapat menjawab 1 atau semua dari pertanyaan yang ada sesuai dengan yang dirasakan narapidana kemudian mencentangnya dan skala HARS ini juga memiliki 4 kategori yaitu tidak cemas, cemas ringan, cemas sedang dan cemas berat. 
Sedangkan Skala Likers memiliki 30 butir analisis data seperti perhitungan statistik dan pernyataan dengan jawaban SS (Sangat proses pengujian hipotesis tidak perlu Sesuai), S (Sesuai), TS (Tidak Sesuai) dan disajikan. Tabel dan grafik dapat digunakan STS (Sangat Tidak Sesuai) dengan untuk memperjelas penyajian hasil penelitian mencentang salah satu jawaban atas secara verbal, dan harus diberi komentar atau pernyataan yang ada selanjutnya skala Likers dibahas. memiliki 3 kategori yakni konsep diri rendah, sedang dan tinggi.

Untuk penelitian kualitatif, bagian hasil memuat bagian-bagian rinci dalam bentuk sub topik-sub topik yang berkaitan

\section{HASIL}

Hasil penelitian yang disajikan hanya langsung dengan fokus penelitian dan kategori-kategori. Diketik dalam 1,5 spasi, hasil analisis dan hasil pengujian hipotesis Times New Roman 12pt. saja yang perlu dilaporkan, bukan proses

\section{Analisa Univariat}

Tabel 1

Distribusi Karakteristik Responden Di Rumah Tahanan Kelas II B Majene

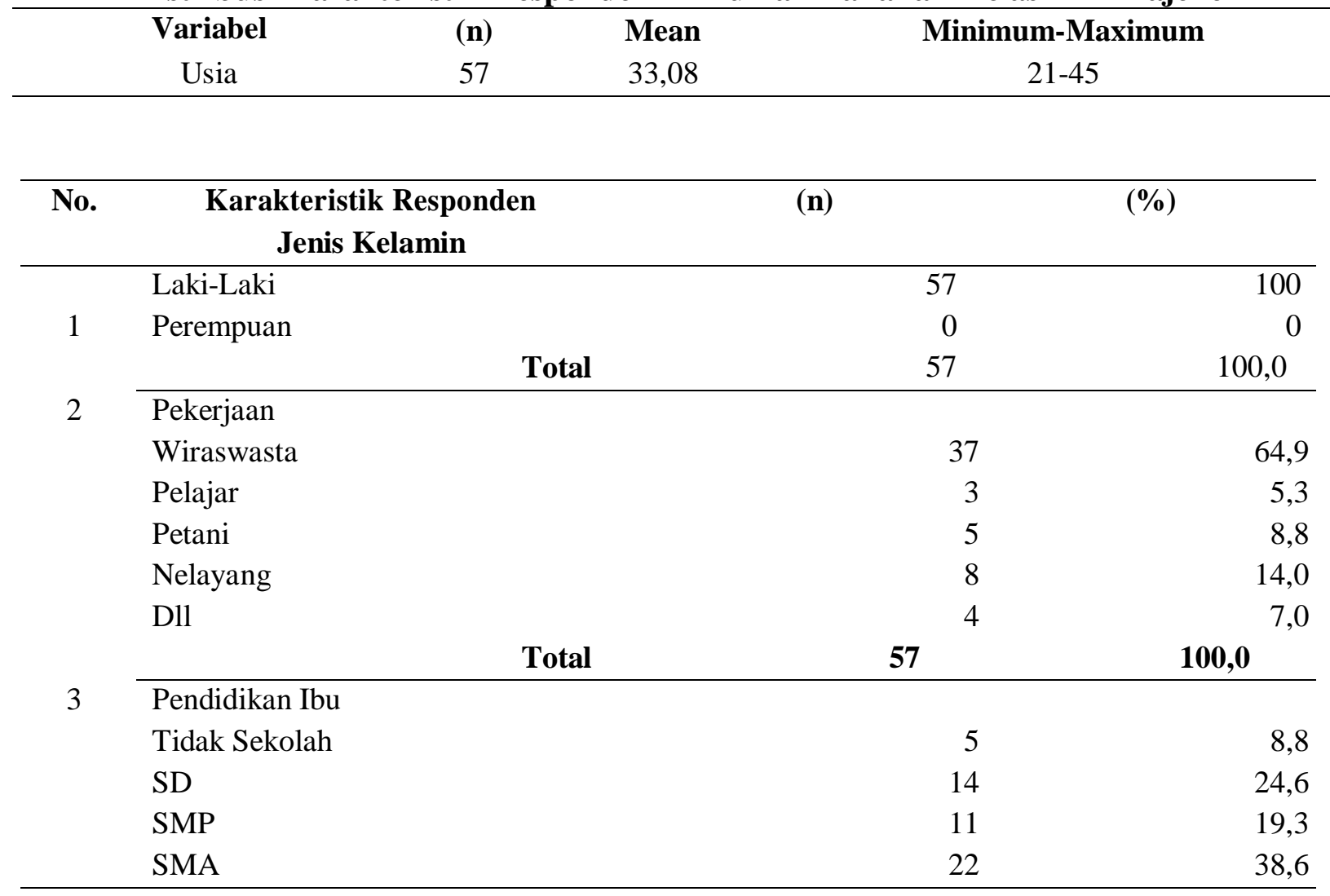




\begin{tabular}{lrrr}
\hline Mahasiswa & 2 & 3,5 \\
DLL & Total & 3 & 5,2 \\
\cline { 2 - 4 } & $\mathbf{5 7}$ & $\mathbf{1 0 0 , 0}$ \\
\hline
\end{tabular}

\begin{tabular}{cccc}
\hline Variabel & (n) & Mean & Minimum-Maximum \\
\hline Usia & 57 & 62,16 & $10-174$ \\
\hline
\end{tabular}

Tabel 2

Distribusi Responden Berdasarkan Tingkat Konsep Diri dan Tingkat Kecemasan

\begin{tabular}{|c|c|c|c|c|c|c|}
\hline No. & Variabel & & (n) & \multicolumn{2}{|c|}{$(\%)$} & \\
\hline \multirow[t]{5}{*}{1} & Konsep Diri & & & & & \\
\hline & Rendah & & 20 & & 35,1 & \\
\hline & Sedang & & 18 & & 31,6 & \\
\hline & Tinggi & & 19 & & 33,3 & \\
\hline & & Total & & 57 & & 100,0 \\
\hline \multirow[t]{6}{*}{2} & Kecemasan & & & & & \\
\hline & Tidak Cemas & & 2 & & 3,5 & \\
\hline & Cemas Ringan & & 22 & & 36,5 & \\
\hline & Cemas Sedang & & 24 & & 42,1 & \\
\hline & Cemas Berat & & 9 & & 15,7 & \\
\hline & & Total & & 57 & & 42,6 \\
\hline
\end{tabular}

Analisa Bivariat

Tabel 3

Analisa Hubungan Antara Konsep Diri Dengan Kecemasan Narapidana Di Rumah Tahanan Kelas II B Majene

\begin{tabular}{ccccccc}
\hline Variabel & $\begin{array}{c}\text { Tidak } \\
\text { Cemas }\end{array}$ & $\begin{array}{c}\text { Cemas } \\
\text { Ringan }\end{array}$ & $\begin{array}{c}\text { Cemas } \\
\text { Sedang }\end{array}$ & $\begin{array}{c}\text { Cemas } \\
\text { Berat }\end{array}$ & Total & Sign \\
\hline Rendah & 1 & 6 & 10 & 3 & 20 & \\
Sedang & 0 & 9 & 5 & 4 & 18 & \multirow{2}{*}{0,671} \\
Tinggi & 1 & 7 & 9 & 2 & 19 & \\
\hline Total & 2 & 22 & 24 & 9 & 57 & \\
\hline
\end{tabular}

* Uji Chi Square 
Berdasarkan tabel 3 dengan Chi Square narapidana dengan konsep diri rendah dengan kecemasan sedang sebanyak 10 orang, kecemasan ringan sebanyak 6 orang, kecemasan berat sebanyak 3 orang sedangkan tidak cemas sebanyak 1 orang dan untuk konsep diri sedang dengan kecemasan ringan sebanyak 9 orang, kecemasan sedang sebanyak 5 orang, kecemasan berat sebanyak 1 orang sedangkan tidak cemas tidak ada berbeda dengan konsep diri tinggi dengan kecemasan sedang sebanyak 9 orang, kecemasan ringan sebanyak 7 orang, kecemasan berat sebanyak 2 orang dan tidak cemas sebanyak 1 orang. Berdasarkan Uji Statistik dengan uji $C h i$ Square dengan nilai $\mathrm{p}=0,671(\mathrm{p}>0,05)$ yang artinya bahwa tidak ada hubungan yang signifikan antara konsep diri dengan kecemasan narapidana di rumah tahanan Kelas II B Majene.

\section{Pembahasan}

\section{A. Karakteristik Responden}

1. Karakteristik Responden

Berdasarkan Usia

Pada penelitian ini, menunjukkan bahwa dari 57 jumlah responden ratarata usia responden 33 tahun, usia terendah pada responden 21 tahun sedangkan usia tertinggi 45 tahun.

2. Karakteristik Responden Berdasarkan Jenis Kelamin

Pada penelitian ini, menunjukkan bahwa dari 57 responden bejenis kelamin laki-laki sebanyak 57 orang atau $(100 \%)$ dan tidak ada responden berjenis kelamin perempuan.

3. Karakteristik Responden Berdasarkan Pendidikan

Pada penelitian ini, menunjukkan bahwa sebanyak 57 responden dengan pendidikan terakhir dengan persentase tertinggi yakni SMA sebanyak 22 orang $(38,6 \%) \quad$ sedangkan persentase pendidikan terendah yakni mahasiswa sebanyak 2 orang(3,5\%).

4. Karakteristik Responden Berdasarkan Pekerjaan

Pada penelitian ini, menunjukkan bahwa sebanyak 57 responden dengan pekerjaan dengan persentase tertinggi yakni wiraswasta sebanyak 37 orang $(64,9 \%)$, sedangkan persentase terendah yakni pelajar sebanyak 3 orang $(5,3 \%)$.

5. Karakteristik Responden Berdasarkan Lama Tahanan

Pada penelitian ini, menunjukkan bahwa dari 57 jumlah responden rata- 
rata lama tahanan responden sebanyak 62 bulan atau (5 tahun 2 bulan), lama tahanan terendah yaitu 10 bulan dan lama tahanan tertinggi sebanyak 174 atau (14 tahun 5 bulan).

\section{B. Konsep Diri}

Hasil penelitian yang didapatkan berdasarkan tingkat konsep diri terbagi atas 3 yakni konsep diri rendah sebanyak 30 orang $(35,1 \%)$, konsep diri sedang sebanyak 18 orang $(31,6 \%)$ sedangkan konsep diri tinggi sebanyak 19 orang (33,3 $\%)$.

Hasil penelitian menunjukkan bahwa konsep diri memiliki perbedaan yang sangat tipis namun konsep diri pada narapidana di Rutan Kelas II B Majene yang paling banyak adalah konsep diri tinggi sebanyak 19 orang atau $(33,3 \%)$. Hal ini disebabkan karena narapidana memiliki koping yang bagus selama berada dalam penjara serta mampu mengenali dirinya.

Berdasarkan hasil wawancara dengan beberapa narapidana di Rutan Kelas II B Majene mayoritas mereka mengatakan bahwa, banyaknya pengetahuan yang didapatkan dengan berbagi pengalaman antara narapidana serta sipir tahanan selama berada dalam Rutan Kelas II B
Majene sehingga narapidana dapat mengetahui tentang dirinya dan mampu menerima keadaan.

Hasil penelitian ini selaras dengan penelitian yang dilakukan oleh (Utami, 2018) penerimaan terhadap keadaan sebagai seorang narapidana dapat dilakukan dengan pengenalan pada konsep diri. Narapidana yang memiliki konsep diri yang positif dapat menunjukkan sikap optimis, percaya diri serta mampu berfikir positif segala sesuatunya termasuk kegagalan dengan melihat kegagalan merupakan pelajaran akan masa depan. Kegagalan dapat juga menimbulkan konsep diri negatif dengan menganggap dirinya tidak berguna serta takut tidak diterima oleh keluarga.

Konsep diri yang positif mampu mengenali dirinya, menghargai dirinya serta melihat masa depannya dengan mengetahui kelebihan dan kekurangannya sedangkan konsep diri yang negatif tidak mampu melihat potensi serta keterbatasan yang dimilikinya. Hasil penelitian ini sejalan dengan penelitian yang dilakukan oleh (Adriawati, 2012) dengan pola konsep diri pada narapidana dapat terbentuk melalui proses belajar dalam interaksinya dengan lingkungan di penjara karena individu tidak lahir dari konsep diri 
melainkan konsep diri terbentuk seiring dengan perkembangan konsep diri dimana interaksi individu dengan orang lain yang memberikan pengaruh secara langsung maupun tidak langsung.

\section{Kecemasan}

Hasil penelitian didapatkan berdasarkan tingkat kecemasan narapidana dengan tingkat kecemasan tidak cemas sebanyak 2 orang $(3,5 \%)$, cemas ringan sebanyak 22 orang $(38,6 \%)$, cemas sedang sebanyak 24 orang $(42,1 \%)$ sedangkan cemas berat sebanyak 9 orang $(15,8 \%)$.

Dari data diatas dapat ditarik kesimpulan bahwa mayoritas narapidana yang berada di Rutan Kelas II B Majene memiliki tingkat kecemasan sedang yakni sebanyak 24 orang $(42,1 \%)$. Hal ini dapat disebabkan karena narapidana yang berada dalam penjara rentang mengalami kecemasan. Berdasarkan observasi dan wawancara yang dilakukan oleh peneliti terhadap beberapa narapidana mayoritas mereka mengatakan bahwa mereka merasa cemas dengan keluarganya yang berada dirumah namun karena adanya program pembinaan yang ada di Rutan Kelas II B Majene seperti program kelas budaya dan litererasi, kerajinan tangan, dan program pembinaan lainnya sangat membantu narapidana untuk terus produktif meskipun di dalam penjara sehingga kecemasan yang dialami dapat berkurang dengan adanya kegiatan tersebut.

Secara konsep bahwa seseorang yang mengalami kecemasan sedang yakni memiliki persepsi yang sempit, hanya mampu fokus pada satu titik yang penting namun masih mampu dalam melakukan arahan dari orang lain (Kusumawati \& Hartano, 2011) Begitupun dengan narapidana yang berada di Rutan Kelas II B Majene mayoritas narapidana tersebut memiliki kecemasan sedang namun masih mampu untuk melakukan arahan dari orang lain, seperti mengikuti program pembinaan yang dilaksanakan di Rutan Kelas II B Majene.

Wawancara juga di lakukan pada narapidana yang menjelang bebas mereka mengatakan bahwa mereka merasa khawatir dan kurang percaya diri terhadap stigma mantan narapidana pada masyarakat telah melekat pada dirinya. Berbeda dengan wawancara yang dilakukan pada narapidana yang baru masuk mayoritas narapidana mengatakan bahwa mereka hanya merasa cemas dengan kondisi keluarganya saat ini, namun karena keluarga sering berkunjung maka rasa cemas dan khawatir masih dapat dikendalikan. Selain mendapatkan 
dukungan sosial dari kunjungan keluarga atau teman-teman sesama penghuni Lapas, narapidana juga mendapatkan dukungan sosial dari pegawai Lapas yaitu berupa biro konsultasi yang mempunyai dua tenaga psikologis sehingga membuka peluang bagi semua narapidana untuk membantu mengatasi masalahnya. Selain itu narapidana juga diberikan dukungan dalam bentuk pembinaan secara keagamaan, penyaluran bakat dalam bentuk olahraga atau musik sehingga narapidana merasakan kepedulian, dukungan, dan penghargaan yang berasal dari pegawai dan penghuni Lapas. dengan demikian, hal ini menjadi salah satu penyebab narapidana yang berada di Rutan Kelas II B Majene mengalami tingkat kecemasan sedang.

Hasil penelitian ini sejalan dengan penelitian yang dilakukan oleh (Amelia, 2010) dengan judul Hubungan Dukungan Sosial Dengan Kecemasan Menghadapi Masa Pembebasan Pada Narapidana Di Lembaga Pemasyarakatan Kelas II A Pekanbaru dimana Jika narapidana memperoleh dukungan sosial yang tinggi maka kecemasan dalam menghadapi masa pembebasan pada narapidana akan semakin rendah. Sebaliknya, jika narapidana memperoleh dukungan sosial yang rendah maka kecemasan dalam menghadapi masa pembebasan pada narapidana akan semakin tinggi.

\section{Hubungan Konsep diri dengan}

\section{Kecemasan}

Berdasarkan hasil penelitian yang dilakukan oleh peneliti didapatkan hasil konsep diri rendah dengan kecemasan sedang sebanyak 10 orang, kecemasan ringan sebanyak 6 orang, kecemasan berat sebanyak 3 orang sedangkan tidak cemas sebanyak 1 orang dan untuk konsep diri sedang dengan kecemasan ringan sebanyak 9 orang, kecemasan sedang sebanyak 5 orang, kecemasan berat sebanyak 1 orang sedangkan tidak cemas tidak ada berbeda dengan konsep diri tinggi dengan kecemasan sedang sebanyak 9 orang, kecemasan ringan sebanyak 7 orang, kecemasan berat sebanyak 2 orang dan tidak cemas sebanyak 1 orang. Berdasarkan Uji Statistik Chi Square dengan nilai $\mathrm{p}=0,671(\mathrm{p}>0,05)$ yang artinya bahwa tidak ada hubungan yang signifikan antara konsep diri dengan kecemasan narapidana pada rumah tahanan Kelas II B Majene.

Dari hasil penelitian hubungan konsep diri dengan kecemasan maka dapat ditarik kesimpulan bahwa tidak hubungan bermakna antara konsep diri dengan kecemasan pada narapidana di Rutan Kelas 
II B Majene. Berdasarkan tanggapan dari hasil wawancara dengan narapidana, mereka mengatakan bahwa di Lembaga di Rutan mereka mendapatkan program pembinaan yang disesuaikan dengan keahlian masing-masing seperti pembuatan karya kerajinan tangan, program kelas budaya dan literasi sehingga kegiatankegiatan seperti ini membuat mereka mampu mengembangkan potensi diri dan lebih produktif meskipun di dalam penjara.

Hasil penelitian yang dilakukan oleh (Amelia, 2010) dimana kecemasan yang dialami oleh narapidana dalam menghadapi masa pembebasan akan sangat tergantung dari dukungan yang mereka dapatkan, apabila narapidana mendapatkan dukungan yang baik dan positif dari keluarga dan petugas Lembaga Pemasyarakatan badi dari segi perhatian emosional, bantuan intrumental, mendapatkan informasi yang dibutuhkan dan adanya penilaian yang baik terhadap narapidana akan membuat narapidana akan menjalani masa pembebasan terhindar dari rasa kecemasan sebaliknya apabila kebebasan yang mereka didapatkan tidak didukung yang baik dan positif dari keluarga dan petugas Lembaga Pemasyarakatan badi dari segi perhatian emosional, bantuan intrumental, mendapatkan informasi yang dibutuhkan dan adanya penilaian yang baik terhadap narapidana akan mengakibatkan narapidana mengalami kecemasan untuk dapat berada di lingkungan masyarakat.

Hasil wawancara peneliti dengan salah satu sipir atau Pegawai Rutan Kelas II B Majene memberikan penjelasan bahwa program pembinaan selama di Lembaga Pemasyarakatan ini bertujuan untuk memberdayakan warga rutan dan mengasah kemampuan sehingga output dari pembinaan ini dapat menjadikan narapidana untuk lebih percaya diri serta produktif sehingga setelah bebas dari penjara mampu menghasilkan uang dari karya inovasi. Hal tersebut berkaitan dengan individu yang memiliki konsep diri yang positif akan mengetahui kelebihan dan kekurangan, menghargai dirinya, optimis dalam memandang masa depannya serta dapat menyelesaikan masalahnya sedangkan konsep diri negatif tidak mengetahui kekurangannya, potensi serta peluang yang dimiliki. Namun, stigma bagi narapidana sebagai mantan narapidana menjadi salah satu masalah ketika narapidana akan kembali ke masyarakat.

Hasil penelitian ini sejalan dengan penelitian yang dilakukan oleh (Nugroho, 2015)yang menyatakan bahwa pandangan 
masyarakat mengenai mantan narapidana akan dipengaruhi oleh budaya masyarakat memandang kriminalitas sebagai hal yang tabu. Pandangan tersebut dilatarbelakangi oleh pengalaman pribadi, pengetahuan dan pengaruh media massa yang menyatakan bahwa mantan narapidana sebagai sumber permasalahan, sampah masyarakat, orang jahat, individu yang harus diwaspadai dan dapat melakukan kembali tindakan kriminal.

Secara konsep jika individu mengetahui tentang dirinya maka tingkat kecemasan akan rendah sebaliknya jika individu tidak mengetahui tentang dirinya maka kecemasannya akan tinggi (Ekajaya, 2019) namun, berbeda dengan penelitian ini yakni tidak ada hubungan antara konsep diri dengan kecemasan. Berdasarkan hasil wawancara peneliti terhadap narapidana menjelang bebas mayoritas narapidana mengatakan bahwa perasaan cemas dan khawatir yang dialaminya disebabkan karena keluarganya yang tidak lagi berkunjung ke penjara dan perasaan khawatir terhadap stigma masyarakat terhadap dirinya sebagai mantan narapidana. Namun mereka mengaku bahwa selama di dalam penjara lebih mendekatkan diri kepada Tuhan selain itu program pembinaan yang diberikan di selama di Rutan mampu membuat dirinya percaya diri untuk terus produktif setelah keluar dari penjara. Sehingga, dengan demikian hal ini menjadi faktor penyebab tidak adanya hubungan konsep diri dengan kecemasan pada narapidana di Rutan Kelas II B Majene.

Hasil penelitian ini sejalan dengan penelitian yang dilakukan oleh (Kusumaningsih, 2017) dengan hasil penelitian mengatakan bahwa seburuk apapun pengalaman yang pernah dialami bahkan oleh narapidana sekalipun membuktikan bahwa hal tersebut dapat terjadi pada siapa saja. Penerimaan diri menuntut adanya kemauan untuk dapat mengubah pengalaman buruk tersebut menjadi salah satu kondisi yang menguntungkan. Karena, dengan menerima kenyataan hidup sebagai seorang narapidana, disisi lain justru dapat menjadi salah satu teknik yang menenangkan dalam mengatasi kecemasan yang dialami atau bahkan dapat menjadi motivasi untuk lebih baik lagi di kemudian hari.

Dengan demikian, agar seorang narapidana tetap dapat melanjutkan kehidupannya tanpa harus mengalami kecemasan akan penilaian masyarakat terkait status sebagai narapidana adalah 
dengan memiliki keyakinan penuh dan percaya akan kemampuan diri yang dimilikinya untuk tetap dapat melanjutkan hidup tanpa rasa rendah diri dan tetap menghargai diri sebagai manusia yang sederajat dengan manusia lainnya disertai rasa tanggung jawab untuk tidak mengulangi kesalahan di kemudian hari.

Berdasarkan hasil diatas dapat ditarik kesimpulan bahwa konsep diri tidak mempengaruhi kecemasan ketika individu mengetahui dirinya dan apa yang menjadi harapan dalam diri individu tersebut. Begitupun dengan narapidana yang berada di Rutan Kelas II B memiliki konsep diri rendah dengan tingkat kecemasan sedang artinya mayoritas narapidana tidak terlalu cemas serta khawatir terhadap dirinya selama berada di Rutan Kelas II B Majene.

\section{Kesimpulan}

Berdasarkan hasil dapat disimpulkan bahwa hipotesis ditolak yang artinya tidak ada hubungan antara konsep diri dengan kecemasan narapidana pada Rumah Tahanan Kelas II B Majene.

\section{Ucapan Terima Kasih}

Para Pegawai RUTAN Kelas II B Majene yang ikut serta membantu peneliti selama proses penelitian yang dilakukan sehingga dapat berjalan dengan lancar dan seluruh responden yang telah bersedia sebagai sampel dalam penelitian ini.

\section{Daftar Pustaka}

1. Adriawati, S. (2012). Hubungan Konsep Diri Dengan Kecemasan Narapidana Menghadapi Masa Depan Di Lembaga Pemasyarakatan Wanita Malang. Skripsi .

2. Amelia, K. (2010). Hubungan Dukungan Sosial Dengan Kecemasan Menghadapi Masa Pembebasan Pada Narapidana Di Lembaga Pemasyarakatan Kelas Ii A Pekan Baru. Skripsi .

3. Ekajaya, D. S. (2019). Hubungan Antara Kepercayaan Diri Dengan Kecemasan Sosial Pada Narapidana Menjelang Bebas Di Lembaga Pemasyarakatan Klas Ii A Muaro Padang. Psyche .

4. Fitrotussalamah. (2016). Hubungan Konsep Diri Dengan Kecemasan Narapidana Remaja Di Lpka Kelas I Blitar Menjelang Bebas. Skripsi .

5. Frans, H. (2014). Kecemasan Pada Narapidana Di Lembaga Pemasyarakatan Narkotika Kelas Ii A Way Hui Bandar Lampung. Skripsi .

6. ICJR (2019). Data Institute For Criminal Justice Reform.

7. Kanwil. (2019). Data Terakhir Jumlah Penghuni Per-Upt Pada Kanwil.

8. Kusumaningsih, L. (2017). Penerimaan Diri Dan Kecemasan Terhadap Status Narapidana. Intuisi Jurnal Psikologi Ilmiah .

9. Kusumawati, F., \& Hartano, Y. (2011). Buku Ajar Keperawatan Jiwa. Jakarta: Salemba Medika.

10. Nugroho, H. (2015). Hubungan Konsep Diri Dan Kecemasan Narapidana Menjelang Bebas Di Lembaga 
Pemasyarakatan Kelas Ii A Wirogunan Yogyakarta. Skripsi .

11. Potter, P., \& Perry, A. (2010). Fundamental Keperawatan, Edisi 7 Buku 2. Jakarta: Salemba Medika.

12. Putra, R. (2019). Hubungan Antara Konsep Diri Dengan Kecemasan Sosial Pada Narapidana Pria Kasus Narkotika Di Lembaga Pemasyarakatan Kelas Ii A Padang. Psyche .
13. Salim, S. U. (2016). Gambaran Faktor Yang Mempengaruhi Kecemasan Wbp Menjelang Bebas Di Lp Wanita Kelas Ii A Bandung. Ilmu Keperwatan .

14. Stuart, G. (2009). Buku Saku Keperawatan Jiwa. Jakarta: Egc.

15. Utami, W. (2018). Pengaruh Persepsi Stigma Sosial Dan Dukungan Sosial Terhadap Kesejahteraan Psikologis Pada Narapidana . An-Nafs , 183-270. 